\title{
Chiral $\beta$-Hydroxyalkyloxazolines as Ligands in the Enantioselective Addition of Diethylzinc to Aldehydes
}

\section{Celso L. Wosch ${ }^{1}$, Francisco A. Marques ${ }^{{ }^{*}}$, Gustavo Frensch ${ }^{1}$, Ricardo Labes ${ }^{1}$, Beatriz Helena L. N. Sales Maia ${ }^{1}$, Cesar A. Lenz ${ }^{2}$, Palimecio G. Guerrero Jr. ${ }^{3}$}

${ }^{1}$ Departamento de Química,Universidade Federal do Paraná, Centro Politécnico, Jardim das Américas, 81531-990 - Curitiba - PR, Brazil

\author{
${ }^{2}$ Instituto de Tecnologia do Paraná, Cidade Industrial, 81350-010 - Curitiba, PR, Brazil \\ ${ }^{3}$ Departamento de Química e Biologia, Universidade Tecnológica Federal do Paraná, Centro, 80230-901 - \\ Curitiba - PR, Brazil
}

*Corresponding author. Tel.: 005541 3361-3177 Fax: 005541 3361-3186 e-mail: tic@ufpr.br

Keywords: Diethylzinc, stereoselective addition, aryl aldehydes, $\beta$-hydroxyalkyloxazolines

\section{INTRODUCTION}

The inherent nature of chirality results in extraordinary specificity of biological systems to recognize chiral molecules. Efforts to control the chirality of molecules resulted in major advances in the field of chemical catalysis. The development of various drugs as pure enantiomers, along with a variety of other biologically active compounds, would not have been possible without the advances of studies based on asymmetric catalysis in recent decades. Among the challenges found in the stereoselective synthesis of organic molecules, it is included the development of low cost ligands and catalysts. ${ }^{1-4}$ Here we report our results involving the addition of diethylzinc to aryl aldehydes using $\beta$ hydroxyalkyloxazolines $\mathbf{1}, \mathbf{2}, \mathbf{3}$ and 4 as chiral ligands (Figure 1).
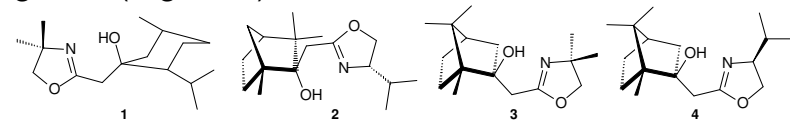

Figure 1: $\beta$-hydroxyalkyloxazolines 1, 2, 3 and 4

\section{RESULTS AND DISCUSSION}

The first stage of the work involved the synthesis of chiral $\beta$-hydroxyalkyloxazolines through the addition of lithium oxazoline anions to menthone, fenchone and camphor, yielding compounds 1, 2, 3 and 4, respectively. With all the ligands prepared, diethylzinc could be added to aryl aldehydes in enantiomeric excess ranging from 69 to $93 \%$ (Scheme 1).

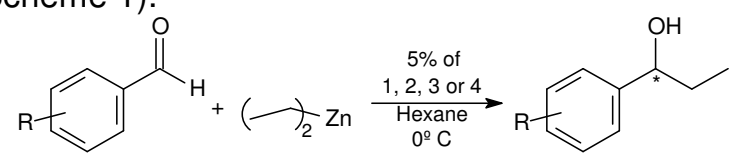

The best enantioselectivities were achieved employing the ligand $\mathbf{4}$ in the addition processes.

Table 1. Yields and e.e. of $\mathrm{Et}_{2} \mathrm{Zn}$ addition on aldehydes using ligand $\mathbf{4}$

\begin{tabular}{cccc}
\hline Aldehyde & Yield (\%) & e.e. (\%) & Configuration \\
\hline $\mathrm{C}_{6} \mathrm{H}_{5} \mathrm{CHO}$ & 95 & 90,8 & $S$ \\
$p-\mathrm{ClC}_{6} \mathrm{H}_{4} \mathrm{CHO}$ & 93 & 90,4 & $S$ \\
$o-\mathrm{CH}_{3} \mathrm{OC}_{6} \mathrm{H}_{4} \mathrm{CHO}$ & 90 & 85.4 & $S$ \\
$m-\mathrm{CH}_{3} \mathrm{OC}_{6} \mathrm{H}_{4} \mathrm{CHO}$ & 92 & 93,1 & $S$ \\
$p-\mathrm{CH}_{3} \mathrm{OC}_{6} \mathrm{H}_{4} \mathrm{CHO}$ & 93 & 92,4 & $S$ \\
\hline
\end{tabular}

\section{CONCLUSION}

The chiral $\beta$-hydroxyalkyloxazolines prepared permitted the addition of diethylzinc to aryl aldehydes in good yields and in moderate to good enantiomeric excesses.

\section{ACKNOWLEDGEMENTS}

The authors thank CNPq-National Institute of Science and Technology for the Biorational Control of Pest-Insect, CAPES-Procad and Fundação Araucária for financial support.

\section{REFERENCES}

1. Stymiest, J. L.; Bagutski, V.; French, R. M.; Aggarwal, V. K.; Nature, 2008, v. 456, p. 778-782.

2. Weickgenannt, A.; Mewald, M.; Oestreich, M.; Organic \& Biomolecular Chemistry, 2010, v. 8, p. 1479-1504

3. Wu, X.; Xiao, J.; Chem. Comm., 2007, p. 2449-2466.

4. Teichert, J. F.; Feringa, B. L.; Angew. Chem. Int. Ed., 2010, v. 49 , p. 2486-2528.

Scheme 1. Addition of $\mathrm{Et}_{2} \mathrm{Zn}$ to aldehydes.

$14^{\text {th }}$ Brazilian Meeting on Organic Synthesis $-14^{\text {th }}$ BMOS - September 01-05, 2011-Brasilia, Brazil 